\title{
Pharmacologically significant tetraaza macrocyclic metal complexes derived from isatin and 3,4-diaminobenzophenone: Synthesis, spectral studies and comparative in vitro biological assessment
}

\author{
MOHAMMAD SHAKIR ${ }^{\mathrm{a}, *}$, NAUSHEEN BANO ${ }^{\mathrm{a}}$, MOHAMMAD AHMAR RAUF $^{\mathrm{b}}$ and \\ MOHAMMAD OWAIS ${ }^{\mathrm{b}}$ \\ ${ }^{a}$ Department of Chemistry, Aligarh Muslim University, Aligarh, Uttar Pradesh 202 002, India \\ b Interdisciplinary Biotechnology Unit, Aligarh Muslim University, Aligarh, Uttar Pradesh 202 002, India \\ E-mail: shakir078@yahoo.com
}

MS received 10 June 2017; revised 23 October 2017; accepted 23 October 2017; published online 22 November 2017

\begin{abstract}
The 12-membered Schiff base macrocyclic complexes, [Dichloro [5,6;11,12-dibenzophenone1,4,7,10-tetraazacyclododeca-1,3,7,9-tetraene-2,3,8,9-diindole] metal(II) [M = $\mathrm{Co}$ (II), $\mathbf{1} ; \mathrm{Ni}(\mathrm{II}), \mathbf{2} ; \mathrm{Cu}(\mathrm{II}), \mathbf{3}$ and $\mathrm{Zn}(\mathrm{II}), 4]$ were synthesized via template condensation of isatin and 3,4-diaminobenzophenone. These four complexes were characterized employing the analytical, spectral viz., FTIR, NMR, Mass, UV-Vis, EPR, TGA/DTA and SEM. The formation of metal complexes has been confirmed on account of the characteristic band positions in FTIR spectra and resonance signals in NMR spectra while the absorption bands in UV-Vis spectra and magnetic moment analysis signify the geometry of the complexes. However, the EPR study inferred distorted octahedral geometry in $\mathrm{Cu}$ (II) complex. The binding profile of the metal complexes (1-4) with CT-DNA was monitored by fluorescence and circular dichroism (CD) spectroscopy coupled with molecular docking studies. The binding constants were found to be highest for complex 3 . Further, the hypothesis of preferential binding in the minor groove of double-stranded DNA is supported by CD and docking results. The antioxidative properties showed substantial radical scavenging potency of the complex $\mathbf{3}$. The comparative in vitro antibacterial study of the metal complexes against different pathogenic microbes (S. aureus, E. coli and C. albicans) revealed enhanced activity for complex $\mathbf{3}$ which is further certified by its efficacy to resist biofilm formation as investigated by XTT reduction assay.
\end{abstract}

Keywords. Macrocyclic complexes; spectral studies; antibacterial activity; DNA binding study; antioxidant activity.

\section{Introduction}

During the past decades, macrocyclic complexes of Schiff bases have been emerging as a focused area of research interest attracting the attention of both inorganic and bioinorganic chemists globally. ${ }^{1}$ An important class of ligands consists of Schiff bases derived from the condensation of carbonyl and an amino group containing compounds that coordinate to metal ions through azomethine nitrogen. These Schiff bases ligands possess a broad spectrum of pharmacological activities such as antitumor, antibacterial, antifungal and anticancer activities. $^{2}$ The macrocyclic ligand formation incriminates

\footnotetext{
*For correspondence
}

metal ion template to orient the reactant groups of the linear substrate in the desirable confirmation for the ring closure rather than an oligomeric or polymeric product. ${ }^{3}$ The unfavorable entropy is overcome by favorable enthalpy for the formation of metal-ligand bonds (ML) ordering the multidentate ligand around metal ion and thus, promoting the cyclization reaction. ${ }^{4}$ In general, macrocyclic complex formation depends on the size and rigidity of the internal cavity of the macrocycle. ${ }^{5}$ The metal complexes of Schiff bases obtained from heterocyclic moieties comprising of $\mathrm{S}, \mathrm{N}$ and/or $\mathrm{O}$ as ligand atoms are of great importance as simple structural biological models. ${ }^{6}$ Hence, biological properties of carbocycles (a ring composed exclusively of 
carbon atoms) are reduced rather than the macrocyclic complexes consisting of heterocyclic moieties in the macrocyclic rings in which macrocyclic framework having pendant arms can enhance the selectivity of the ligand for a given ion allowing fine-tuning of the metal complexes properties. ${ }^{7}$ Isatin (1H-indole-2,3-dione), is a privileged scaffold and among the most promising class of heterocyclic compound that possesses many interesting activity profiles and tolerated well in humans, and have acquired significant applications in medicinal chemistry because of their wide spectrum of biological activities. ${ }^{8-10}$ There have been many studies involving various metal complexes of Schiff base macrocycles derived from isatin derivatives. ${ }^{11}$ In view of their pharmacological and biological properties, the isatin based Schiff base macrocyclic compounds opened up a new vista of promising prospects in synthetic organic chemistry. ${ }^{12}$ The antibacterial and antioxidant parameters are vital for the prevention of human diseases. Antioxidant compounds may act as free radical scavengers, playing a crucial role in the degradation of food and chemical materials, considerably preventing the oxidation of readily oxidizable substances. ${ }^{13}$ The formation of high levels of reactive oxygen species (ROS) including hydrogen peroxide, superoxide anion and hydroxyl radical resulting from various physiological or biochemical processes or by pollution and other exogenous sources, can be harmful to the body and may damage all the major components of cells (DNA, proteins, and cell membranes) leading to several diseases, such as arthritis, inflammation, ageing, cancer, cardiovascular, pulmonary and neurodegenerative disorders. ${ }^{14,15}$ The free radical formation in different diseases has developed the curiosity for the exploration of compounds which are termed as antioxidants that resist the formation of free-radicals or compounds which may act as oxygen radical scavenger. ${ }^{16}$ Isatin-based drug candidates have already been pursued in the pharmaceutical and medicinal industries. For example, the multiple tyrosine kinase receptor inhibitors Semaxanib and TSU68 were discovered as the emerging class of compounds among the class of small-molecule inhibitors to develop a potential anticancer treatment. ${ }^{17}$ Structurally, Semaxanib and TSU-68 are close analogs of Sunitinib (orally administered tyrosine kinase inhibitor approved for the treatment of the metastatic renal cell carcinoma) as it contains isatin motif. ${ }^{18}$ Recently, the advancement in antibiotic-resistant microorganisms has led to an increase in demand for new antibiotics. ${ }^{19}$ The biofilms are microbial communities which are coupled to the surface and often embedded in a hydrated matrix of polysaccharide and protein. ${ }^{20}$ Biofilm formation increases the resistance to antimicrobial agents that restrict the eradication of microorganism (the bacteria within biofilms are 10-1000 times more resistant to antibiotics and chemical agents). ${ }^{21-23}$ The biofilm formation is common in foodstuff and marine industry along with medical sector (up to $60 \%$ of the total human infections are provoked by biofilms). ${ }^{24-26}$ The Candida biofilms formation has an important clinical application on the grounds of increased resistance to antifungal therapy and its ability to withstand host immune defenses. Among this division, Candida albicans is the major species inducing life-threatening infections among immunocompromised individuals like HIV and patients relying on a distinct variety of implants. Therefore, there is an alarming call to search alternatives to the conventional drugs to encounter C. albicans biofilm. ${ }^{27}$

DNA is an important drug target, regulating various biochemical processes that occur in the biological system. ${ }^{28}$ Cisplatin (cis-diamminedichloroplatinum (II) or cis- $\left.\left[\mathrm{PtCl}_{2}\left(\mathrm{NH}_{3}\right)_{2}\right]\right)$ is the most potent antitumor drug available in the cancer chemotherapy of solid tumors such as lung, ovarian, head, neck and bladder cancers. Cisplatin promotes cancer cell death through binding with DNA. ${ }^{29}$ However, cisplatin is nephrotoxic, shows poor water solubility, exhibits intrinsic resistance and covalent mode of their interaction with DNA which limits its clinical efficacy. ${ }^{30}$ Hence, considerable attention is focused to design new metal complexes as anticancer drugs which involve non-covalent modes of interaction with DNA. ${ }^{31}$ The interaction of transition metal complexes with DNA has been extensively studied during the last decade because many compounds expose their antitumor activity through binding with DNA and can cause DNA damage of cancer cells by blocking the cell division that results in cell death. ${ }^{32}$ The Schiff bases have drawn considerable application in the field of bioinorganic because of their structural variability, stability and biocompatibility. ${ }^{33}$

Considering the earlier report from our lab which demonstrated that both the carbonyl group of isatin reacts with amine group, ${ }^{34}$ an effort has been made to synthesize pharmacologically active 12-membered tetraaza Schiff base macrocyclic complexes comprising of isatin and 3,4-diaminobenzophenone via template condensation reaction for the metal series of $\mathrm{Co}$ (II), $\mathrm{Ni}(\mathrm{II}), \mathrm{Cu}(\mathrm{II})$ and $\mathrm{Zn}$ (II) (Scheme 1) and characterized via various physicochemical and spectroscopic techniques. To investigate the binding mode of complexes with DNA, fluorescence and circular dichroism studies were performed. However, the molecular docking studies were undertaken for complexes $\mathbf{3}$ and $\mathbf{4}$. Furthermore, the pharmacological efficacy of the newly synthesized complexes was explored by examining their antioxidant, antimicrobial, antibiofilm activities. 
2<smiles>Nc1ccc(C(=O)c2ccccc2)cc1N</smiles>

3,4-diaminobenzophenone

$\mathrm{MCl}_{2} \cdot \mathrm{nH}_{2} \mathrm{O}$

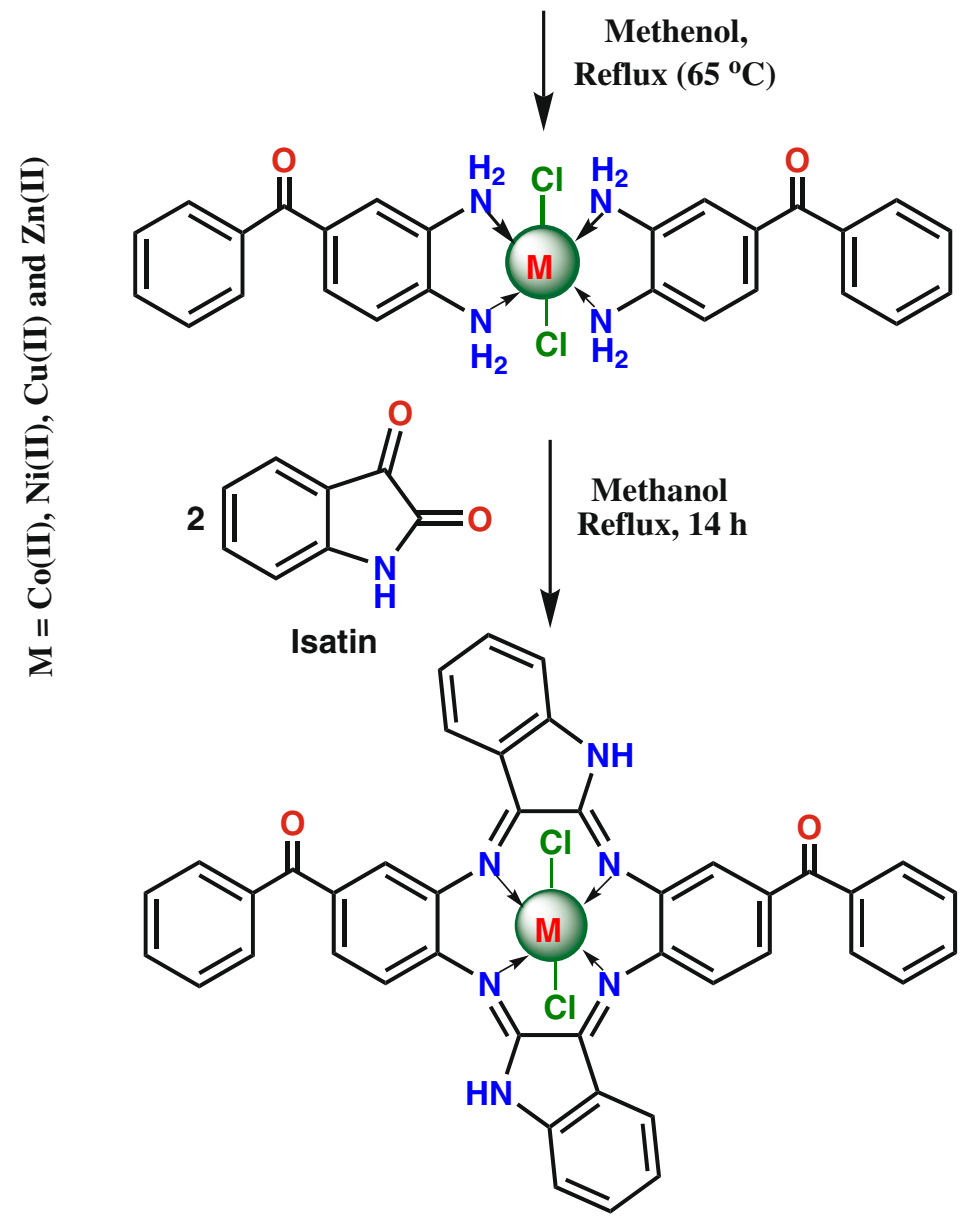

Dichloro[5,6;11,12-dibenzophenone-1,4,7,10-tetraazacyclododeca-1,3;7,9-tetraene-2,3;8,9 diindole]M(II)

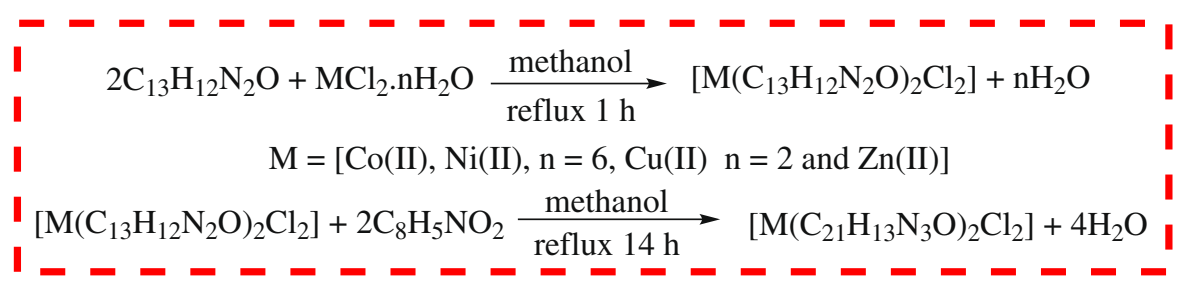

Scheme 1. Schematic illustration of Schiff base macrocyclic complexes of $\mathrm{Co}(\mathrm{II}), \mathbf{1} ; \mathrm{Ni}(\mathrm{II}), \mathbf{2} ; \mathrm{Cu}(\mathrm{II}), \mathbf{3}$; and $\mathrm{Zn}(\mathrm{II}), 4$.

\section{Experimental}

\subsection{Materials and methods}

Isatin, 3,4-diaminobenzophenone, EB [Ethidium Bromide], CT DNA [Calf Thymus], DPPH [2, 2-diphenyl-1-picrylhy- drazyl], ascorbic acids and XTT [(2, 3-Bis-(2-Methoxy-4Nitro-5-Sulfophenyl)-2H-Tetrazolium-5 Carboxanilide)] and RPMI 1640 were procured from Sigma-Aldrich, USA. All the chemicals and solvents were used as supplied without further purification. The metal salts, $\mathrm{MCl}_{2} \cdot \mathrm{nH}_{2} \mathrm{O}[\mathrm{M}=\mathrm{Co}, \mathrm{n}=$ 
6; $\mathrm{M}=\mathrm{Ni}, \mathrm{n}=6 ; \mathrm{M}=\mathrm{Cu}, \mathrm{n}=2 ; \mathrm{M}=\mathrm{Zn}$ (Aldrich) were commercially available pure samples. Microanalytical data (C, H and N) were obtained from Flash 2000 CHN elemental analyzer at CIL-Chandigarh, India. NMR spectra were recorded in DMSO - $\mathrm{d}_{6}$ using a Bruker Avance II 400 NMR Spectrometer. The FT-IR $\left(4000-400 \mathrm{~cm}^{-1}\right)$ was recorded on FTIR; Interspec 2020, spectrolab U.K. using as KBr disc. ESI mass spectra were certified on a Q-ToF (Water Company) mass spectrometer. The electronic spectra $\left(10^{-3} \mathrm{M}\right.$, range 200-800 nm) of the complexes in DMSO were performed on Perkin Elmer $\lambda$-25 spectrophotometer at room temperature. The EPR spectra for $\mathrm{Cu}(\mathrm{II})$ and $\mathrm{Co}(\mathrm{II})$ complexes were recorded on JEOL JES-FA200 electron spin resonance (ESR) at $298 \mathrm{~K}$ and ES-DVT4 Spectrometer at liquid nitrogen temperature (LNT), respectively. The evaluation of magnetic susceptibility was carried out using a Faraday balance at room temperature. The molar conductivity data $\left(10^{-3}, \mathrm{molL}^{-1}\right)$ in DMSO solutions were recorded on a Systronic type 302 conductivity bridge equilibrated at $25^{\circ} \mathrm{C} \pm 0.01$. To analyze the thermal stability of complexes TGA/DTA study was performed on a Shimadzu DTG-60H system (Japan) under $\mathrm{N}_{2}$ flow $\left(20 \mathrm{~mL} \mathrm{~min}^{-1}\right)$ with a heating rate of $10^{\circ} \mathrm{C} / \mathrm{min} .{ }^{35}$ The sample morphology was recorded onto carbon tapping copper stubs and before SEM observations, the samples were coated with gold in the JEOL-JFC-1600 auto fine coater for $50 \mathrm{~s}$ at $20 \mathrm{~mA}$ and then coated samples were mounted into a sample holder for the SEM analysis at different magnifications. ${ }^{36}$ The in vitro antimicrobial assessment of the compounds was performed using both disk diffusion and broth micro dilution methods. The antibiofilm potential of synthesized compound (complex $\mathbf{3}$ ) was also determined by using XTT assay. The free radical scavenging property of the Schiff base macrocyclic complexes is commonly evaluated using DPPH method.

\subsection{Synthesis of Schiff base tetraaza macrocyclic} complexes: Dichloro[5,6;11,12-dibenzophenone1,4,7,10-tetraazacyclododeca-1,3,7,9-tetraene-2,3,8,9diindole $]$ metal(II), $\left[\mathrm{MLCl}_{2}\right]$ where $M=\mathrm{Co}(\mathrm{II})$, $\mathrm{Ni}(I I), \mathrm{Cu}(\mathrm{II})$ and $\mathrm{Zn}(\mathrm{II})$

All the complexes were synthesized by template method where the methanolic solution $(30 \mathrm{~mL})$ of 3,4-diaminobenzophenone ( $0.42 \mathrm{~g}, 2 \mathrm{mmol})$ was treated with metal(II) chloride $(1 \mathrm{mmol})$ dissolved in methanol $(15 \mathrm{~mL})$. The resulting dark color solution was refluxed on a water bath for half an hour followed by the addition of isatin $(0.29 \mathrm{~g}, 2 \mathrm{mmol})$ in methanol $(30 \mathrm{~mL}$ ). The refluxing was continued for $10-12 \mathrm{~h}$ and the resulting mixture was concentrated to half of its volume and cooled to room temperature and allowed to stand overnight. The precipitate thus formed was filtered, washed thoroughly with methanol and dried in vacuo over fused $\mathrm{CaCl}_{2}$.

2.2a $\quad\left[\mathrm{Co}(\mathrm{II}) \mathrm{LCl}_{2}\right](\mathbf{1})$ : Yield: 65\%; Colour: chocolate. M.p.: $290^{\circ} \mathrm{C}$. Molar Conductance $\left(1 \times 10^{-3} \mathrm{M}, \mathrm{DMSO}\right): \wedge_{\mathrm{m}}$ $\left(27 \mathrm{~mol}^{-1} \mathrm{~cm}^{2} \Omega^{-1}\right)$. Anal. Calc. for $\mathrm{C}_{42} \mathrm{H}_{26} \mathrm{~N}_{6} \mathrm{O}_{2} \mathrm{Cl}_{2} \mathrm{Co}$ : C,
64.95; H, 3.37; N, 10.80; O, 4.12. Found: C, 64.82; H, 3.12; N, 10.69; O, 4.07\% IR $\left(\mathrm{KBr}, \mathrm{cm}^{-1}\right): 1668(\mathrm{C}=\mathrm{O})$, $1604(\mathrm{C}=\mathrm{N}), 3277(\mathrm{~N}-\mathrm{H}), 3030(\mathrm{C}-\mathrm{H}), 452(\mathrm{M}-\mathrm{N})$. UV-vis $\left(\lambda_{\max } / \mathrm{nm}\right): 688,454,351,279$. ESI-MS $(\mathrm{m} / \mathrm{z})=776.53$. Found: $[\mathrm{M}+\mathrm{H}]^{+}=777.26$.

2.2b $\quad\left[\mathrm{Ni}(\mathrm{II}) \mathrm{LCl}_{2}\right](2)$ : Yield: 47\%; Colour: Brick red. M.p.: $275^{\circ} \mathrm{C}$. Molar Conductance $\left(1 \times 10^{-3} \mathrm{M}, \mathrm{DMSO}\right): \wedge_{\mathrm{m}}$ $\left(28 \mathrm{~mol}^{-1} \mathrm{~cm}^{2} \Omega^{-1}\right)$. Anal. Calc. for $\mathrm{C}_{42} \mathrm{H}_{26} \mathrm{~N}_{6} \mathrm{O}_{2} \mathrm{Cl}_{2} \mathrm{Ni}$ : C, 64.98; H, 3.37; N, 10.82; O, 4.12. Found: C, 64.87; H, 3.39; N, 10.72; O, 4.23\% IR $\left(\mathrm{KBr}, \mathrm{cm}^{-1}\right): 1678(\mathrm{C}=\mathrm{O}), 1615(\mathrm{C}=\mathrm{N})$, $3265(\mathrm{~N}-\mathrm{H}), 3062(\mathrm{C}-\mathrm{H}), 490(\mathrm{M}-\mathrm{N})$. UV-vis $\left(\lambda_{\max } / \mathrm{nm}\right)$ : 715, 626, 336, 280. ESI-MS (m/z) = 776.29 Found: 776.91 .

2.2c $\quad\left[\mathrm{Cu}(\mathrm{II}) \mathrm{LCl}_{2}\right](3)$ : Yield: $61 \%$ Colour: Cinnamon. M.p.: $250^{\circ} \mathrm{C}$. Molar Conductance $\left(1 \times 10^{-3} \mathrm{M}\right.$, DMSO $): \wedge_{\mathrm{m}}$ $\left(23 \mathrm{~mol}^{-1} \mathrm{~cm}^{2} \Omega^{-1}\right)$. Anal. Calc. for $\mathrm{C}_{42} \mathrm{H}_{26} \mathrm{~N}_{6} \mathrm{O}_{2} \mathrm{Cl}_{2} \mathrm{Cu}: \mathrm{C}$, 64.57; H, 3.35; N, 10.75; O, 4.09. Found: C, 64.49; H, $3.31 ; \mathrm{N}, 10.61 ; \mathrm{O}, 4.01 \%$ IR $\left(\mathrm{KBr}, \mathrm{cm}^{-1}\right): 1640(\mathrm{C}=\mathrm{O})$, $1595(\mathrm{C}=\mathrm{N}), 3350(\mathrm{~N}-\mathrm{H}), 3080(\mathrm{C}-\mathrm{H}), 510(\mathrm{M}-\mathrm{N})$. UV-vis $\left(\lambda_{\max } / \mathrm{nm}\right): 561,462,335,284$. ESI-MS $(\mathrm{m} / \mathrm{z})=781.14$. Found: $[\mathrm{M}+\mathrm{H}]^{+}=782.08$.

2.2d $\left[\mathrm{Zn}(\mathrm{II}) \mathrm{LCl}_{2}\right]$ (4): Yield: 59\% Colour: Rust. M.p.: $40^{\circ} \mathrm{C}$. Molar Conductance $\left(1 \times 10^{-3} \mathrm{M}\right.$, DMSO $): \wedge_{\mathrm{m}}(40-$ $\mathrm{mol}^{-1} \mathrm{~cm}^{2} \Omega^{-1}$ ). Anal. Calc. for $\mathrm{C}_{42} \mathrm{H}_{26} \mathrm{~N}_{6} \mathrm{O}_{2} \mathrm{Cl}_{2} \mathrm{Zn}$ : C, 64.42; H, 3.34; N, 10.73; O, 4.08. Found: C, 64.29; H, 3.11; N, 10.66; O, 4.03\% IR $\left(\mathrm{KBr}, \mathrm{cm}^{-1}\right): 1650(\mathrm{C}=\mathrm{O})$, $1610(\mathrm{C}=\mathrm{N}), 3335(\mathrm{~N}-\mathrm{H}), 3085(\mathrm{C}-\mathrm{H}), 515(\mathrm{M}-\mathrm{N}) .{ }^{1} \mathrm{H}$ NMR $\left(\mathrm{DMSO}_{\mathrm{d}}, \mathrm{ppm}\right): 12.10$ (s, C-NH-C, 2H), 7.37-8.50 (m, 24H, Ar-H). ${ }^{13} \mathrm{C}$ NMR (DMSO-d 6 , ppm): $195.52(\mathrm{C}=\mathrm{O})$, 143.07 and $137.44(\mathrm{C}=\mathrm{N}), 111.56-133.81$ (Ar-C). ESI-MS $(\mathrm{m} / \mathrm{z}):$ 782.98. Found: $[\mathrm{M}+\mathrm{H}]^{+}=783.80$

\subsection{DNA binding study}

2.3a Solution preparation for DNA binding: A stock solution of the compounds was made by dissolving the complex in an aqueous solution of DMSO as the co-solvent and dilution were made with the corresponding phosphate buffer $(\mathrm{pH}=7.2)$ to obtain desired concentrations. The final DMSO concentration was kept below $0.3 \% \mathrm{v} / \mathrm{v}$. The CT-DNA concentration was determined by the absorption intensity at $260 \mathrm{~nm}$ using the molar absorption coefficient value of $6600 \mathrm{M}^{-1} \mathrm{~cm}^{-1}$. The purity of CT-DNA solution was confirmed by UV absorbance ratio (A260/A280 = 1.9), indicating that CT-DNA is free from protein impurity. ${ }^{37}$

2.3b Fluorescence spectroscopy: The fluorescence titration measurements were performed on spectrofluorophotometer model RF-5301 (Shimadzu Japan) at $25 \pm 0.1{ }^{\circ} \mathrm{C}$ with a $1.00 \mathrm{~cm}$ optical path length cell, equipped with a 150 W Xenon lamp and both the excitation and emission slits were adjusted at $5 \mathrm{~nm}$ and $10 \mathrm{~nm}$, respectively. The Intrinsic fluorescence was recorded by exciting the CT-DNA solution at $478 \mathrm{~nm}$ and emission spectra were carried out in 500-700 $\mathrm{nm}$ range. To evaluate the binding parameters, 1:1 ratio of 
DNA-EB $(50 \mu \mathrm{M})$ complex solution was taken in a quartz cell and the fluorimetric titrations were done with increasing concentration of tested compound $(0-70 \mu \mathrm{M})$.

2.3c Circular dichroism (CD) measurements: The secondary structural changes in CT-DNA were recorded on JASCO CD J-815 spectropolarimeter equipped with a Peltier-type temperature controller at $25^{\circ} \mathrm{C}$ using Quartz cuvettes of $1 \mathrm{~cm}$ path length. Two scans were accumulated at a scan speed of $100 \mathrm{~nm} \mathrm{~min}{ }^{-1}$, with data being collected in the far-UV range of $230-320 \mathrm{~nm}$ under $\mathrm{N}_{2}$ atmosphere. CD spectra of CT-DNA in absence and presence of compounds $(0-20 \mu \mathrm{M})$ were also recorded and the respective blanks were subtracted from each spectrum.

\subsection{Free radical scavenging activity}

The free radical scavenging property of the synthesized Schiff base macrocyclic complexes were assessed with the DPPH (2,2-diphenyl-1-picrylhydrazyl) method. ${ }^{38}$ DMSO was used for the preparation of different concentrations of the test compounds $(50-450 \mu \mathrm{g} / \mathrm{mL}) .3$ $\mathrm{mL}$ of DPPH $(0.1 \mathrm{mM})$ methanolic solution was added to the tubes containing $1 \mathrm{~mL}$ of sample solution of variable concentration and the resulting mixture was shaken vigorously and kept at ambient temperature. After 30 min incubation period, the absorbance of test solutions was measured at $517 \mathrm{~nm}$. The experiment for the control was performed as mentioned before without the test samples. The experiments were performed in duplicate. The DPPH scavenging ability of the compounds was determined by the following equation:

$\% \operatorname{RSA}=\left[\left(\mathrm{A}_{\mathrm{o}}-\mathrm{A}_{\mathrm{c}}\right) / \mathrm{A}_{\mathrm{o}}\right] \times 100$

where RSA = radical scavenging activity, $\mathrm{A}_{\mathrm{o}}=$ absorbance of ascorbic acid (reference) and $\mathrm{A}_{\mathrm{c}}=$ absorbance of test compounds at concentration, $\mathrm{c}$.

\subsection{In vitro antimicrobial assay}

The bacterial strains (Escherichia coli, ATCC-25922; and Staphylococcus aureus, ATCC-25923) were inoculated into molten Nutrient Broth and incubated at $37^{\circ} \mathrm{C}$ for $24 \mathrm{~h}$ while the fungal cells (Candida albicans, MTCC-183) were inoculated into YPD Broth at $24^{\circ} \mathrm{C}$ for $48 \mathrm{~h}$.

2.5a Determination of antibacterial activity by agar diffusion assay: The antibacterial activities of the complexes evaluated in terms zone of inhibition using disk diffusion method against E. coli as Gram-negative bacteria and S. aureus as Gram-positive bacteria while C. albicans was considered as a candidate for in vitro antifungal assay. ${ }^{39}$ The pure cultures of microorganism were sub-cultured in broth at $35^{\circ} \mathrm{C} \pm 2{ }^{\circ} \mathrm{C}$. A lawn of culture was adjusted for bacterial growth by spreading $100 \mu \mathrm{L}$ fresh culture with $10^{6} \mathrm{CFU} / \mathrm{mL}$ of a test organism on nutrient agar plates using sterile glass rod. Afterwards, the plates were kept for a suitable period of time to get absorbed. Finally, the wells $(6 \mathrm{~mm}$ diameter) were punched into the seeded agar plates and loaded with $10 \mu \mathrm{L}$ volume having a concentration of $10 \mathrm{mg} / \mathrm{mL}$ of the tested compounds followed by incubation of plates at $37^{\circ} \mathrm{C}$ for $24 \mathrm{~h}$ and subsequently, the diameter of inhibition zone around each disk was measured. The antibacterial activity of a common standard antibiotic Gentamicin and antifungal Amphotericin B was also recorded using the same procedure as above using the same concentration and solvents. Each experiment was done in triplicate to minimize the deviations.

$$
\begin{aligned}
& \% \text { activity Index } \\
& =\frac{\text { Zone of inhibition by test compound (diameter) }}{\text { Zone of inhibition on by standard (diameter) }} \times 100
\end{aligned}
$$

\section{5b Determination of minimum inhibitory concentra-} tion assay: The lowest concentration of an antimicrobial compound which inhibits the visible growth of microorganisms after $24 \mathrm{~h}$ of the incubation period is termed as MIC. The MICs are decisive to assure the resistance of microorganisms to antimicrobial agents. The broth microdilution assay was performed based on the method of NCCLS, $2008 .{ }^{40}$ For the evaluation of MIC $(\mu \mathrm{g} / \mathrm{mL})$, the test compounds were taken in $5 \%$ DMSO (which has no activity against test microorganisms) to make $10 \mathrm{mg} / \mathrm{mL}$ of concentration to get final concentration of $1 \mathrm{mg} / \mathrm{mL}$ by proper dilution and the controls were inoculated with approximately $\sim 10^{5}$ $\mathrm{CFU} / \mathrm{mL}$ of actively dividing bacteria. The experiments were performed in duplicate. The bacterial culture plates were incubated for $18-24 \mathrm{~h}$ at $37^{\circ} \mathrm{C}$ and the fungal strains were incubated at $24^{\circ} \mathrm{C}$ for $24-48 \mathrm{~h}$. The MICs for different test compounds were monitored visually and spectrophotometrically after the incubation period.

\subsection{Interaction between bacteria and Schiff base complex: SEM analysis}

For SEM analysis of respective bacterial and fungal cells, a reported protocol was followed. ${ }^{41}$ Briefly, in 6 well cell culture plates, biofilm formation was initiated on sterile cover slip discs by distributing a standardized cell suspension ( $2 \mathrm{~mL}$ of a suspension containing $1 \times 10^{6}$ cells $/ \mathrm{mL}$ in RPMI 1640) onto proper discs at 
$37^{\circ} \mathrm{C}$ for $2 \mathrm{~h}$. Finally, the non-adherent cells for biofilm formation were removed by washing. The cover slip discs were kept for incubation in $400 \mu \mathrm{L}$ of RPMI media for another $24 \mathrm{~h}$. Thereafter, the cover slips were loaded with $200 \mu \mathrm{g} / \mathrm{mL}(50 \mu \mathrm{L})$ of the treated compound for $30 \mathrm{~min}$. The discs were withdrawn and washed thrice completely in sterile PBS. The biofilms were fixed in $4 \%$ [vol/vol] formaldehyde and $1 \%$ [vol/vol] glutaraldehyde in PBS for $24 \mathrm{~h}$. Then samples were rinsed thoroughly using $0.1 \mathrm{M}$ PBS and subsequently in $1 \%$ osmium tetraoxide for $30 \mathrm{~min}$. The samples were dehydrated afterwards through a series of ethanol washes and finally dried to observe under SEM.

\subsection{XTT biofilm assay}

The biofilms assay was performed using the polystyrene, sterile, 96-well microtiter plates. Following the incubation $(2 \mathrm{~h})$ of respective bacterial and fungal cell suspension (at the density of $10^{7}$ cells) in the wells at $37^{\circ} \mathrm{C}$, the plates were rinsed three times with PBS to remove loosely attached and un-adhered cells. Further, the plates were incubated with $100 \mu \mathrm{L}$ per well of RPMI media for another $4 \mathrm{~h}$ at $37^{\circ} \mathrm{C}$ to allow the biofilm development. After $4 \mathrm{~h}$ of incubation, when biofilms were still developing, the biofilms were given dark exposure of treated sample i.e, complex 3 . Consequently, the plates were incubated at $37^{\circ} \mathrm{C}$ for another $20 \mathrm{~h}$. Finally, the sodium salt of XTT was dissolved in Phosphate buffer to $1 \mathrm{mg} / \mathrm{mL}$ concentration, filter-sterilized and stored at $-80^{\circ} \mathrm{C}$. Menadione was dissolved in acetone to 1 $\mathrm{mM}$ followed by immediate sterilization before each experiment. $100 \mu \mathrm{L}$ of XTT/menadione solution was then added to each well of a microtiter plate with gentle shaking using rotator incubator $(100 \mathrm{rpm})$, then covered (in dark) and incubated at $37^{\circ} \mathrm{C}$ for $5 \mathrm{~h}$. The colorimetric change by water-soluble formazan product was measured at $450 \mathrm{~nm}$ using a microplate reader (BioRad, USA). The wells without biofilms were taken as a blank.

\subsection{Molecular docking}

A molecular graphics program, Hex 8.0.0 was used to understand the interaction between synthesized metal complexes and DNA. Structure of the CT-DNA dodecamer d(CGCGAATTCGCG) $)_{2}$ (PDB ID: 1BNA) was obtained from the protein data bank (http://www.rcsb. org./pdb). The metal complex files were drawn using ChemDraw (MM2) and their energies were minimized using Mercury software and then file was saved in PDB (PROTEIN DATA BANK) format. The water molecules were extracted from the 1BNA using chimera 1.10.2 before operating docking calculations. The extraction of water molecules from the 1BNA were done using chimera 1.10 .2 before performing docking calculations.

\section{Results and Discussion}

A novel series of 12-membered macrocyclic complexes of Schiff bases $\left[\mathrm{M}\left(\mathrm{C}_{42} \mathrm{H}_{26} \mathrm{~N}_{6} \mathrm{O}_{2}\right) \mathrm{Cl}_{2}\right]$, where $\mathrm{M}=\mathrm{Co}(\mathrm{II}), \mathrm{Ni}$ (II), $\mathrm{Cu}(\mathrm{II}), \mathrm{Zn}$ (II), were derived from 3,4-diaminobenzophenone and isatin in a methanolic medium using template condensation method as shown in Scheme 1. The complexes were soluble in DMF and DMSO but insoluble in common organic solvents and water. The molar conductance values obtained for these complexes (in DMSO $10^{-3}, \mathrm{~mol} \mathrm{~L}^{-1}$ ) are in the range of $27-40 \mathrm{~mol}^{-1} \mathrm{~cm}^{2} \Omega^{-1}$ indicated their nonelectrolytic nature, ${ }^{42}$ while the proposed stoichiometry is in accordance with the analytical results. The macrocyclic complexes thus formed were studied through various spectroscopic, physicochemical and biological characterizations.

\subsection{FTIR analysis}

The bands expected in $3200-3400 \mathrm{~cm}^{-1}$ range, characteristic for $v\left(\mathrm{NH}_{2}\right)$ of 3,4-diaminobezophenone were absent in the FTIR spectra of all the complexes. Furthermore, no characteristic absorption band of $v(\mathrm{C}=\mathrm{O})$ group of isatin was observed (at $1735 \mathrm{~cm}^{-1}$ ) that evident the formation of the macrocyclic framework from the condensation of carbonyl groups of isatin and amino groups of 3,4-diaminobenzophenone (Figure S1 in Supplementary Information). A strong absorption band appeared in a range of $1595-1615 \mathrm{~cm}^{-1}$ may be ascribed to $v(\mathrm{C}=\mathrm{N})$ (azomethine group) vibrations while single medium intensity bands of N-H stretching vibrations of the isatin moiety appeared in the range of 3265$3350 \mathrm{~cm}^{-1}$ in all the complexes. ${ }^{43,44}$ However, an intense absorption band observed in the range of 1640-1678 $\mathrm{cm}^{-1}$ of the complexes may be assigned to pendant carbonyl group of 3,4-diaminobenzophenone. ${ }^{45}$ The absorption bands assigned for aromatic $\mathrm{C}-\mathrm{H}$ stretching vibrations were noticed in the range of 3030-3085 $\mathrm{cm}^{-1}$. The absorption bands in the range of 1452 $1477,1045-1069$ and $720-752 \mathrm{~cm}^{-1}$ may be accredited to phenyl ring vibrations. The $\mathrm{C}-\mathrm{N}$ stretching vibrations may occur in the range of $1015-1355 \mathrm{~cm}^{-1}$. The far IR spectra of the complexes showed bands in the region $452-515 \mathrm{~cm}^{-1}$ corresponding to $v(\mathrm{M}-$ $\mathrm{N})$ stretching vibrations which give insight into the coordination of the azomethine nitrogen to the central metal atom. ${ }^{46}$ The bands appeared in the range of $315-330 \mathrm{~cm}^{-1}$ were assigned to $v(\mathrm{M}-\mathrm{Cl})$ stretching vibration. 


\section{$3.2{ }^{1} \mathrm{H}-\mathrm{NMR}$ and ${ }^{13}$ C NMR spectra}

The ${ }^{1} \mathrm{H}-\mathrm{NMR}$ spectrum of a macrocyclic complex of $\mathrm{Zn}$ (II) showed a broad signal at $12.10 \mathrm{ppm}$, possibly assigned to the $\mathrm{NH}$ protons $(\mathrm{s}, 2 \mathrm{H})$ of the isatin moiety ${ }^{47,48}$ [Figure S2(a) in Supplementary Information]. The multiplet appeared in the regions 7.37-8.50 ppm correspond to aromatic ring protons of isatin and 3,4-diaminobenzophenone moiety. ${ }^{49}$ The macrocyclic Schiff base complex fabrication has been validated by the absence of resonance signal expected at 6.24 ppm corresponding to primary amine $\left(\mathrm{NH}_{2}\right)$ of 3,4diaminobenzophenone. ${ }^{50}$

The ${ }^{13} \mathrm{C}-\mathrm{NMR}$ spectrum of $\mathrm{Zn}$ (II) complex revealed strong resonance signal at $195.52 \mathrm{ppm}$ assigned to pendant carbonyl carbons $(>\mathrm{C}=\mathrm{O}$ ) of 3,4-diaminobenzophenone moiety (Figure S2(b) in Supplementary Information). ${ }^{51}$ The absence of a signal at 184 and 159 ppm inferred complete condensation of isatin with 3,4-diaminobenzophenone while the resonance signals observed at 143.07 and 137.44 ppm belonged to characteristic imine functions $(>\mathrm{C}=\mathrm{N}) .{ }^{52}$ Moreover, the presence of the signals in the range of 111.56-133.81 ppm suggested the aromatic carbons in the macrocyclic framework at their appropriate positions related to the proposed structure. ${ }^{53}$

\subsection{Electro spray ionization mass spectra}

The molecular ion peak of four complexes viz. 1, 2, 3 and $\mathbf{4}$ appeared at their respective values 777.26, 776.91, 782.08 and 783.80 (experimental). While the molecular ion peak for simulated mass spectra of complexes 1, 2,3 and $\mathbf{4}$ appear at 776.53, 776.29, 781.14 and 782.98. The difference of mass could be attributed due to the presence of $[\mathrm{M} \pm \mathrm{H}]^{+}$peaks. Also, the presence of peak for complexes 1, 2, 3, and $\mathbf{4}$ at 778.12, 777.92, 783.09 and 784.01 respectively, correspond to the nitrogen isotope. The mass spectra of Schiff base macrocyclic complexes of $\mathrm{Co}(\mathrm{II})$, (a) Ni, (b) $\mathrm{Cu}$ (II), (c) and $\mathrm{Zn}$ (II), (d) have been displayed in Figure S3 (in Supplementary Information).

\subsection{Electronic spectral data}

The UV-visible spectra of all the metal complexes displayed two bands in the range of $270-365 \mathrm{~nm}$ represents $\pi \rightarrow \pi^{*}$ and $\mathrm{n} \rightarrow \pi^{*}$ transitions of aromatic rings and $\mathrm{C}=\mathrm{N}$ groups, respectively (Figure S4 in Supplementary Information). ${ }^{54}$ The electronic spectrum of complex 1 exhibits two absorption bands at 454 and $688 \mathrm{~nm}$, comparable to the characteristic features of octahedral Co(II) complex, ${ }^{55}$ and were reasonably assigned to ${ }^{4} \mathrm{~T}_{1 \mathrm{~g}}(\mathrm{~F}) \rightarrow{ }^{4} \mathrm{~T}_{2 \mathrm{~g}}(\mathrm{~F})$ and ${ }^{4} \mathrm{~T}_{1 \mathrm{~g}}(\mathrm{~F}) \rightarrow{ }^{4} \mathrm{~A}_{2 \mathrm{~g}}(\mathrm{~F})$ transitions, respectively. The observed magnetic moment of $\mathrm{Co}$ (II) complex was found to be 4.82 B.M. at room temperature corresponding to three unpaired electrons, which is comparatively higher than spin-only value, i.e., 3.87 B.M for $\mathrm{d}^{7}$ configuration. This deviation from the spin only value is may be due to the spinorbit coupling. ${ }^{55}$ The spectrum of complex $\mathbf{2}$ exhibited two absorption bands at 626 and $715 \mathrm{~nm}$ which may correspond to ${ }^{3} \mathrm{~A}_{2 \mathrm{~g}}(\mathrm{~F}) \rightarrow{ }^{3} \mathrm{~T}_{1 \mathrm{~g}}(\mathrm{~F})$ and ${ }^{3} \mathrm{~A}_{2 \mathrm{~g}}(\mathrm{~F}) \rightarrow$ ${ }^{3} \mathrm{~T}_{1 \mathrm{~g}}(\mathrm{P})$ transitions, respectively, characteristic of octahedral geometry around $\mathrm{Ni}$ (II) corroborated by the value obtained for magnetic moment in case of $\mathrm{Ni}$ (II) i.e., 3.2 B.M. ${ }^{56}$ The distorted octahedral geometry around $\mathrm{Cu}$ (II) complex, $\mathbf{3}$ was evidenced by its electronic spectrum displaying the two absorption bands at 462 and $561 \mathrm{~nm}$ corresponding to ${ }^{2} \mathrm{~B}_{1 \mathrm{~g}} \rightarrow{ }^{2} \mathrm{~B}_{2 \mathrm{~g}}$ and ${ }^{2} \mathrm{~B}_{1 \mathrm{~g}} \rightarrow{ }^{2} \mathrm{E}_{\mathrm{g}}$ transitions, respectively, ${ }^{57}$ in accordance with the observed magnetic moment value of 1.8 B.M.

\subsection{EPR spectra of $C u(I I)$ and $C o(I I)$ complexes}

The EPR spectrum of $\mathrm{Cu}$ (II) complex, 3 was recorded on $\mathrm{X}$ band at frequency $9.3 \mathrm{GHz}$ under the influence of magnetic field $3260 \mathrm{G}$ at room temperature (300 K) (Figure S5 (a) in Supplementary Information). The spectrum did not exhibit any hyperfine splitting and displayed axial signal. The $\mathrm{Cu}(\mathrm{II})$ complex showed the signal at 2.09 and 2.04 for $\mathrm{g}_{\|}$and $\mathrm{g}_{\perp}$, respectively. The observed trend of $g_{\|}>g_{\perp}>g_{e}(2.0023)$ for the present complex suggested that the unpaired electron was localized in the $\mathrm{d}_{\mathrm{x} 2-\mathrm{y} 2}$ orbital of $\mathrm{Cu}$ (II) ion characteristic of the axial symmetry resulting into a tetragonally elongated structure of $\mathrm{Cu}$ (II) complex. The value of $\mathrm{g}_{\mathrm{av}}$ for the $\mathrm{Cu}$ (II) complex (2.05) was computed from $\mathrm{g}_{\mathrm{av}}^{2}=\mathrm{g}_{\|}^{2}+2 \mathrm{~g}_{\perp}^{2} / 3$ and its deviation from that of the free electron (2.0023) which may be explained in view of the covalent character in M-L bonding which was supported by Kivelson and Neiman. ${ }^{58}$ The greater value of $\mathrm{g}_{\|}$compared to $\mathrm{g}_{\perp}$ indicated axially distorted octahedral geometry. According to Hathaway, the exchange interaction parameter, $\mathrm{G}$, between $\mathrm{Cu}(\mathrm{II})$ centers is derived using the expression $\mathrm{G}=\left(\mathrm{g}_{\|}-2.0023\right) /\left(\mathrm{g}_{\perp}-2.0023\right) .{ }^{59}$ As the value of $\mathrm{G}<4$, the considerable inter-exchange interaction between $\mathrm{Cu}$ (II) centers is expected in the solid state, as compared to $\mathrm{G}>4$ where inter-exchange interaction will be negligible in the solid complex. The calculated $\mathrm{G}$ value (2.32) for the $\mathrm{Cu}$ (II) complex is less than 4 suggestive of copper-copper exchange interactions. Additionally, it is observed that $\mathrm{g}_{\|}>2.30$ which is indicative of an ionic environment and $\mathrm{g}_{\|}<2.30$ represents that the complex has a considerable covalent character in M-L bonding. ${ }^{60}$ The $g_{\|}$value for the 
present complex showed considerable covalent character.

The cobalt ion exhibits two oxidation states (II and III), where $\mathrm{Co}$ (III) with a $t_{2 g}^{6}$ configuration is diamagnetic in nature and hence EPR silent, However, $\mathrm{Co}(\mathrm{II})$ exist in both low spin $(S=1 / 2)$ and high spin $(S=3 / 2)$ states and is paramagnetic, and so can be investigated by EPR spectroscopy. The EPR spectrum of the Co(II) complex was recorded in DMF solution at liquid nitrogen temperature (LNT) because the fast relaxation of $\mathrm{Co}(\mathrm{II})$ broaden the lines at higher temperature. ${ }^{60}$ The values of $g_{\|}$and $g_{\perp}$ observed to be 4.58 and 1.93 , respectively (Figure S5 (b) in Supplementary Information). The high deviation of the $\mathrm{g}$ values from the spin only value i.e., 2.0023, is due to the large angular momentum contribution.

\subsection{TGA/DTA analysis}

The thermal stability of all the complexes represented the degradation of the Schiff base metal complexes which started from $210^{\circ} \mathrm{C}$ and ended at $800^{\circ} \mathrm{C}$ (Table $\mathrm{S} 1$, Figure S6 in Supplementary Information). All the complexes indicated a comparable pattern of decomposition mainly in three steps. Since the thermogram of all the complexes were found to be stable up to $200{ }^{\circ} \mathrm{C}$ indicating the absence of any crystalline/lattice water molecule which was further confirmed by the absence of any endothermic peak in the DTA curve in the range of $20-190{ }^{\circ} \mathrm{C} .{ }^{61}$ In case of complex $\mathbf{1}$, the first decomposition step recorded in the range of $230-430{ }^{\circ} \mathrm{C}$ accompanied by weight loss calcd $55.42 \%$ $(\mathrm{Obs}=56.04 \%)$ corresponds to a loss of two chloride ion and benzophenone moiety supported by an endothermic DTA peak in the range of $250-400^{\circ} \mathrm{C}$. Further, decomposition starts in the range of $430-650^{\circ} \mathrm{C}$ having weight loss calcd $37.82 \%(\mathrm{Obs}=37.38 \%)$ supported by an exothermic DTA peak in the range of $480-620^{\circ} \mathrm{C}$ due to the decomposition of remaining part of organic moieties. However, beyond the $700{ }^{\circ} \mathrm{C}$, the horizontal thermal curve was observed due to the formation of respective metal oxides. ${ }^{62}$

\subsection{SEM analysis of Schiff base compounds}

The fundamental information of the properties such as microstructure, surface morphology and porosity were obtained from SEM micrographs. ${ }^{63}$ The comparisons of SEM micrographs of complexes are shown in Figure 1 . The change in surface morphology of the resultant complexes can be attributed to the coordination of the metal ions to the donor sites of ligand. The micrograph of complex 1 depicted porous honeycomb-like appearance while the micrographs of complex 2 displayed spherically agglomerated, dense structure. However, the micrograph of complex $\mathbf{3}$ depicted non-uniform flowerlike clusters with interconnected network morphology whereas complex $\mathbf{4}$ was characterized by an aggregate of irregularly broken rocks-like shape.

\subsection{Steady-state fluorescence}

The fluorimetric competitive binding probes that can interact with nucleic acids play a crucial role in biophysical studies of macromolecules with chemotherapeutic agents. Therefore, fluorescence quenching analysis using this probe affords additional information relating to the localization of the drugs and their mode of interaction with DNA. During the fluorescent probe, EB (planar cationic dye) has been used since it does not emit fluorescence in view of the quenching effect of solvent molecules.

However, it has been already reported that EB in the presence of DNA emits intense fluorescence due to a high degree of intercalation in between the adjacent base pairs of DNA. ${ }^{64}$ The partial quenching for this enhanced fluorescence can be observed by adding second molecule, ${ }^{65}$ which helps in binding mode determination. The evaluation of binding event of all the Schiff base macrocyclic complexes was performed by fluorescence-quenching experiments with EB-bound to DNA [Table S2, Figure S7 (I) in Supplementary information]. The quenching constant $\mathrm{K}_{\mathrm{sv}}$ was determined from the classical Stern-Volmer Eq. (3). ${ }^{66}$

$\mathrm{F}_{\mathrm{o}} / \mathrm{F}=1+\mathrm{K}_{\mathrm{sv}} \mathrm{Q}$

where $F_{o}$ and $F$ are the fluorescence intensities in the absence and presence of complexes, respectively. The term $\mathrm{K}_{\mathrm{sv}}$ represents linear Stern-Volmer quenching constant while [Q] is the concentration of the complexes (quencher).

The linear Stern-Volmer quenching constant $\mathrm{K}_{\mathrm{sv}}$ can be calculated from the slope. The higher $\mathrm{K}_{\mathrm{sv}}$ value for the complex $3\left(7.75 \times 10^{3} \mathrm{M}^{-1}\right)$ suggested its stronger ability to displace EB from DNA-EB system (Table S2 in Supplementary Information).

$\mathrm{k}_{\mathrm{q}}=\frac{K_{s v}}{\tau_{o}}$

where $\mathrm{k}_{\mathrm{q}}$ is the bimolecular rate constant of the quenching reaction and $\tau_{0}$ is the average lifespan of the fluorophore without a quencher and its value was $\sim$ $10^{-8}$ s. $^{67}$ The $\mathrm{k}_{\mathrm{q}}$ was observed in range of $2.09 \times$ $10^{11}-7.75 \times 10^{11}$ (Table S2) which was greater than 

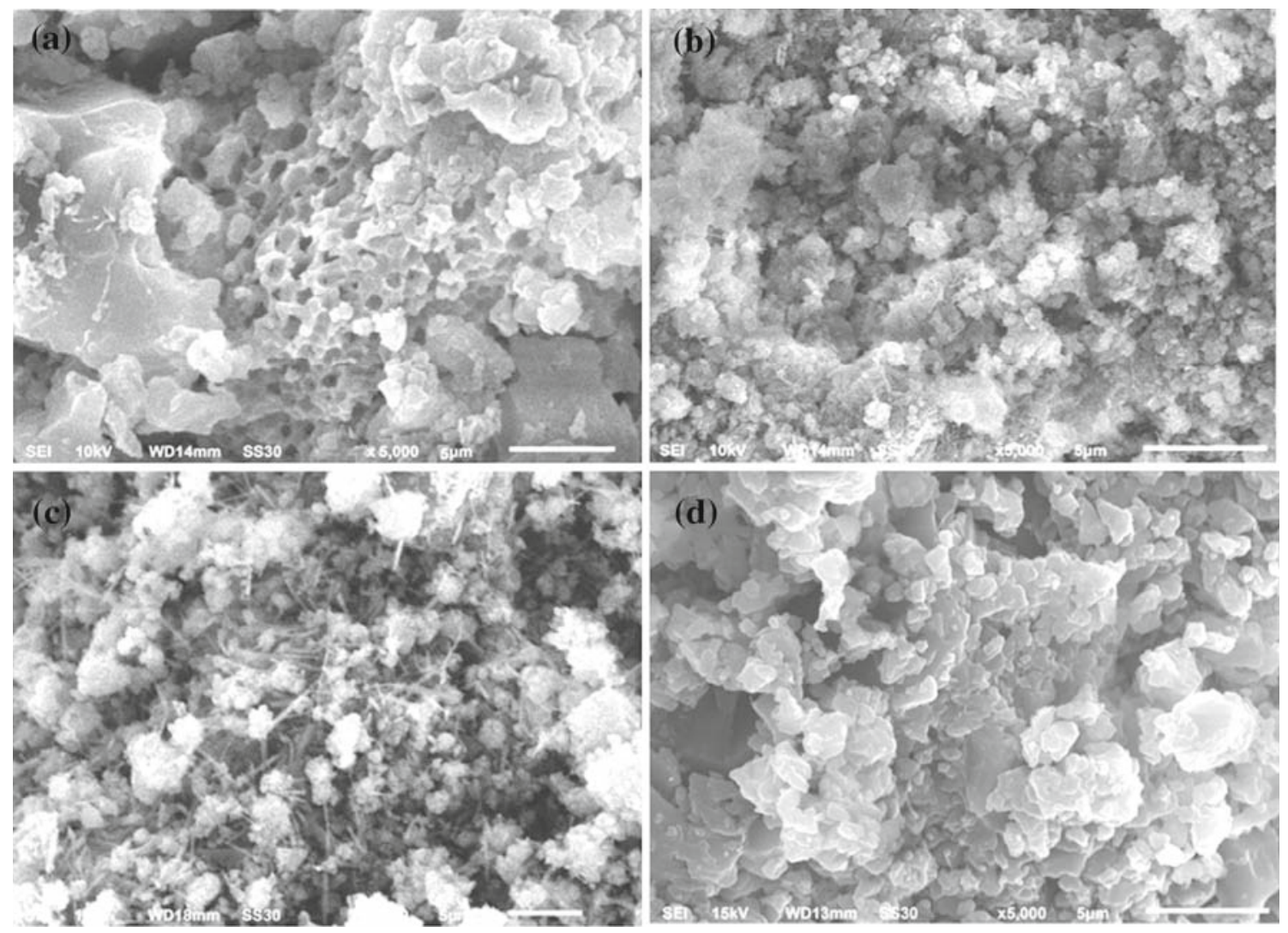

Figure 1. The SEM micrograph of Schiff base macrocyclic complexes of Co(II), (1); Ni(II), (2); Cu(II), (3); and $\mathrm{Zn}(\mathrm{II}),(\mathbf{4})$; (a-d).

the limiting diffusion rate constant of the biomacromolecules $\left(2.0 \times 10^{10} \mathrm{~L} \mathrm{~mol}^{-1} \mathrm{~s}^{-1}\right)$, implying that the static quenching process was observed rather than a dynamic one. ${ }^{68}$

\subsection{Calculation of binding constant}

The decrease in the fluorescence intensity thus warrants the partial replacement of EB bound to DNA by complexes. Successive addition of the metal complexes (1-4) to EB-DNA system, a remarkable decrease in emission intensity was recorded signifying the displacement of EB molecules by the metal complexes from their DNA binding sites. However, the comparative study revealed that complex 3 binds to DNA more strongly as compared to others.

For all the metal complexes with DNA in case of static quenching process, the binding constant $\left(\mathrm{K}_{\mathrm{b}}\right)$ and binding sites number ( $\mathrm{n}$ ) are evaluated by the following Eq. (5). ${ }^{69}$

$\log \left[\left(\mathrm{F}_{\mathrm{o}}-\mathrm{F}\right) / \mathrm{F}_{\mathrm{o}}\right]=\log \mathrm{K}_{\mathrm{b}}+\mathrm{n} \log [\mathrm{DNA}]$

The plots of $\log \left[\left(F_{0}-F\right) / F_{o}\right]$ versus $\log [Q]$ illustrated in Figure S7 (II) and the values of $K_{b}$ and $n$ are shown in Table S2 (Supplementary Information). In addition, it is prominent that the binding constants ascertained for the typical classical intercalators (EB-DNA, $1.4 \times 10^{6}$ $\mathrm{M}^{-1}$ ) are higher in comparison to the metal complexes (1-4). ${ }^{70}$

\subsection{Circular dichroic (CD) spectral studies}

Circular Dichroism is a technique used to monitor the interaction of nucleic acids with drugs, small molecules or metal complexes. ${ }^{71} \mathrm{CD}$ spectrum of CT-DNA display a positive band and a negative band at $275 \mathrm{~nm}$ and 245 $\mathrm{nm}$ due to the base stacking and helicity, respectively which are the characteristic bands of B-form of CT-DNA recorded in the absence of the metal complexes. ${ }^{72}$ Factually, the molecules having the property of classical intercalation show a considerable shift in the intensities of both the bands due to the base stacking interactions and stable conformations, while the electrostatic interaction and simple groove binding demonstrates less perturbation or no change in the base stacking helicity. ${ }^{73}$ To clarify the binding mode (intercalation or groove) of complexes (1-4) with CT-DNA, the CD spectrum was reported in the presence of varying concentration of complexes (Figure S8 in Supplementary Information). The gradual addition of complex to the solution 


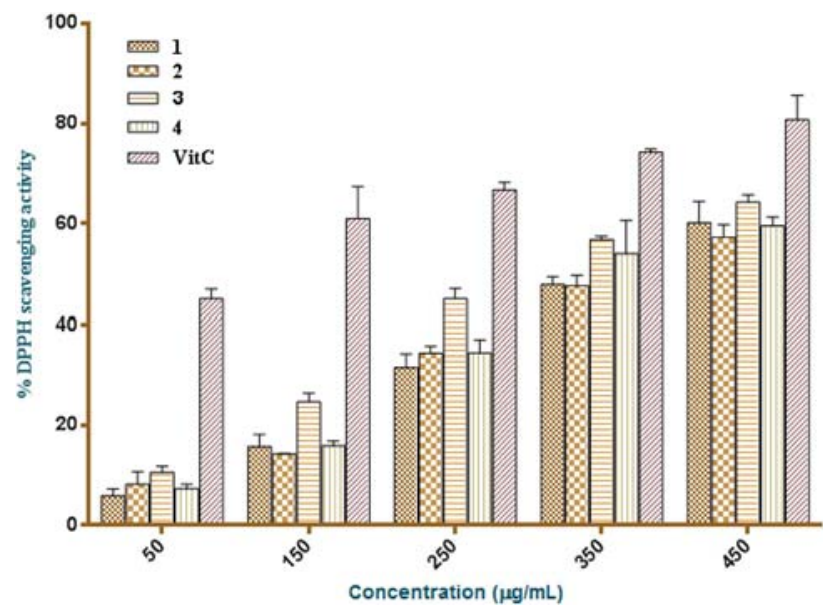

Figure 2. Radical-scavenging activity on DPPH radicals (\%) of the Schiff base synthesized macrocyclic compounds $\mathrm{Co}(\mathrm{II}), \mathbf{1}$; Ni(II), 2; $\mathrm{Cu}(\mathrm{II}), \mathbf{3}$; and $\mathrm{Zn}(\mathrm{II}), 4$.

of CT-DNA does not cause any significant change in the intrinsic CD spectrum of the DNA indicating that binding of complexes with CT-DNA does not alter the stacking of bases. This observation rules out intercalative binding inferring the groove binding mode for all complexes with CT-DNA.

\subsection{DPPH free radical scavenging activity}

Since the newly synthesized Schiff base macrocyclic complexes exhibited good DNA-binding affinity, they are expected to possess antioxidant property. Schiff base macrocyclic complexes were further screened for their in vitro antioxidant activity for free-radical scavenging property by DPPH method at different concentration. ${ }^{74}$ The result varies directly with the different concentrations as shown in Figure 2. All the analyses were done in duplicate and the results are averaged. The results exhibited good radical scavenger activity for all the metal complexes used in this study compared to the reference (Ascorbic acid). The highest inhibition percentage monitored in complex 3 was $64 \%$, which was lower than that of reference at $450 \mu \mathrm{g} / \mathrm{mL}(80 \%)$. The activity difference of complexes may be accredited because of the coordination environment and redox properties. In general, a number of factors such as axial ligation, charge type, coordination number and chelate ring size, the degree of unsaturation and chelate ring substitution pattern are responsible for the complex redox properties. ${ }^{75}$ Thus, it can be concluded that these metal complexes could be beneficial in improving their availability for therapeutic purposes.

The free-radical scavenging mechanism comprising reaction of $\mathrm{O}_{2}^{-}$reacted with $\mathrm{Cu}(\mathrm{II})$ complex, where only a small fraction of $\mathrm{O}_{2}^{-}$reacts with ligand while a large fraction reacts with $\mathrm{Cu}$ (II) and reduces $\mathrm{Cu}(\mathrm{II})$ to $\mathrm{Cu}$ (I). The subsequent oxidation results in the formation of parent $\mathrm{Cu}$ (II) complex with another $\mathrm{O}_{2}^{-}$molecule. ${ }^{76}$ This mechanism also explains the higher free-radical scavenging activity of $\mathrm{Cu}$ (II) complex compared with the other metal complexes.

In case of $\mathrm{Zn}$ (II) complex, it should be noted that imine group is present in ligand framework which exhibits non-innocent behaviour leading to the possibility of its participation in free radical scavenging property. ${ }^{75}$

\subsection{In vitro antimicrobial activity}

The metal complexes were comparatively screened against the bacterial strains as E. coli; gram - ve and $S$. aureus; gram + ve and fungal cells $C$. albicans. The zone of inhibition diameter ( $\mathrm{mm}$ ) was used for the comparative analysis of the antimicrobial activity of the complexes (1-4) with the reference drug (Table S3 and Figure S9 in Supplementary Information). Furthermore, in order to compare the MIC's of the complexes (1-4) against different strains in comparison to reference drug are presented in Table S3 (Supplementary Information). It is concluded that the complexes possess higher zone of inhibition showing lower MIC's and hence act as active antibacterial and antifungal agents. The better antibacterial activity was shown by complex $\mathbf{3}$ which proved their usefulness as potential broad-spectrum antimicrobial agents.

The antibacterial activity of the complexes in terms of structural changes and reactivity, induced by in situ coordination of ligand moiety with the metal ion may be understood in terms of chelation theory. ${ }^{77}$ As a matter of fact, chelation/coordination reduces the polarity of the metal ion because of the partial sharing of its positive charge with donor group within the whole chelate ring system. ${ }^{78}$ Hence, chelation process enhances the lipophilic nature of the central metal atom, favoring its permeation through the lipid layer of the membrane causing metal complex to cross the bacterial membrane more effectively, blocking the metal binding sites of microorganisms. This inhibits the synthesis of the proteins by the complexes which actually restrict the further growth of the microorganisms raising its antibacterial activity. ${ }^{79,80}$

\subsection{Effect of Schiff base compound on bacteria}

The Schiff base macrocyclic compound 3, disrupt the cell morphology in E. coli, S. aureus and C. albicans. The SEM images of treated cells clearly indicated the interference of complex $\mathbf{3}$ with cell membrane integrity, 

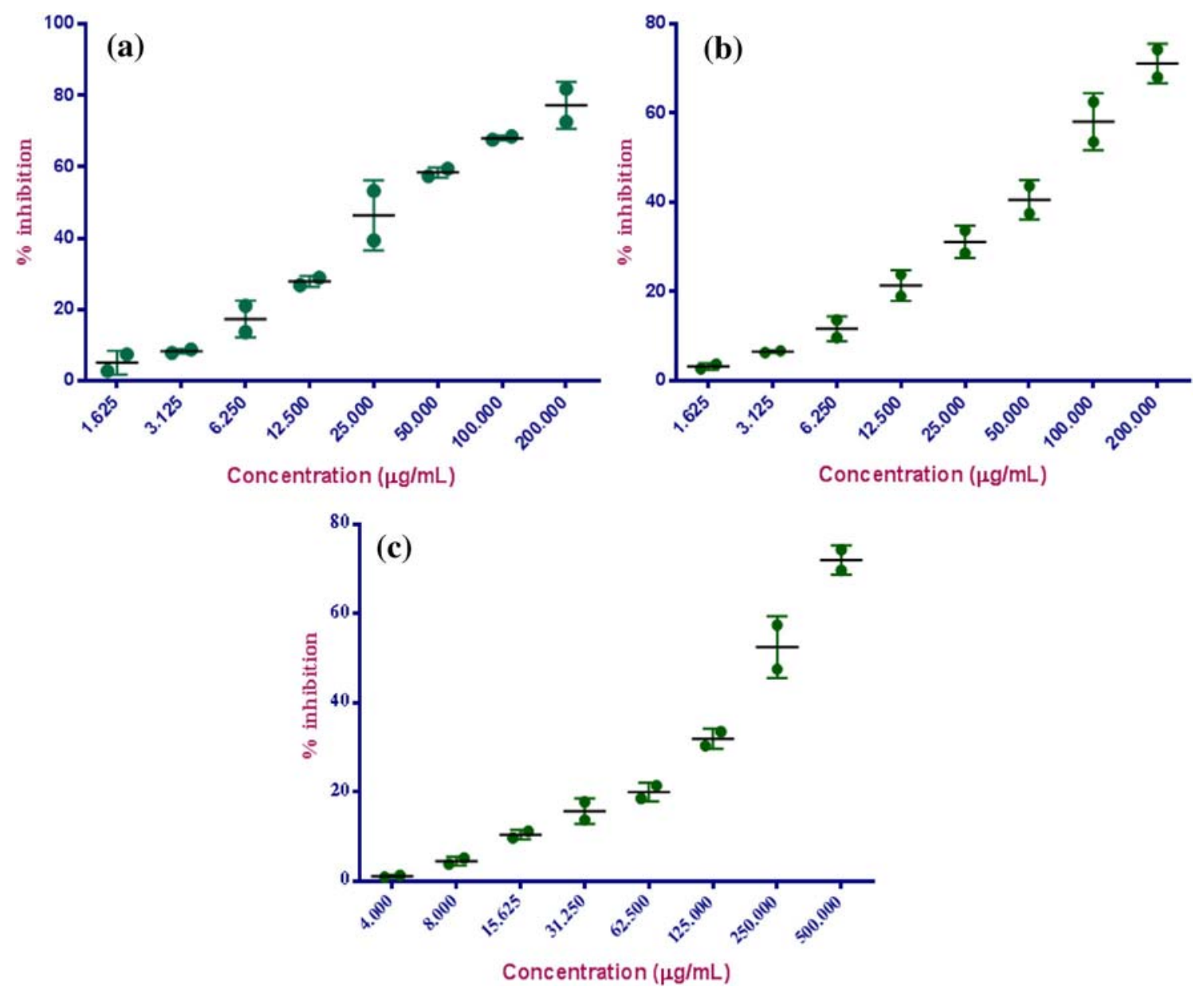

Figure 3. Determination of $\%$ biofilm inhibition of synthesized Schiff base macrocyclic complex of Cu(II), 3 on E. coli (a), S. aureus (b) and C. albicans (c) by XTT method.

as evidenced by shrinkage of the cell surface in biofilm cells without changing the architectural integrity of biofilm and morphology of the cells in control (Figure S10 in Supplementary Information).

\subsection{Biofilm inhibition}

The biofilms act as the double-edged sword being resistant towards antibiotics and immunological barriers. The XTT assay was done quantitatively to assess the potential of complex $\mathbf{3}$ against developing biofilms of E. coli, S. aureus and C. albicans (Figure 3). ${ }^{81}$ This study revealed a varying level of depletion of biofilm formation by respective bacterial and yeast cells in the presence of complex 3 in a dose-dependent manner. The complex 3 at the concentration of $200 \mu \mathrm{g} / \mathrm{mL}$ exhibited $77 \%$ and $71 \%$ inhibition on biofilm formation of E.coli and S. aureus, respectively, while the same complex at a concentration of $500 \mu \mathrm{g} / \mathrm{mL}$ showed $71 \%$ inhibition. Furthermore, the comparative study suggested that complex $\mathbf{3}$ showed the more inhibition against $S$. aureus biofilm.

\subsection{Docking study}

Molecular docking is an attractive computational practice to study the interactions between the drug and DNA for rational drug designing application also for the mechanistic analysis by placing a small molecule inside the binding site of the target specific region of the DNA usually in a non-covalent mode which can validate the spectroscopic results. Molecular modeling provides the flexibility within the ligand to be modeled and can utilize more detailed knowledge about the molecular mechanics to numerate the energy of the ligand in context of the putative active site. To corroborate the groove binding mode, structure of the metal complexes ( $\mathbf{3}$ and 4) was made flexible to acquire different conformations to predict the preferred binding site of $\mathbf{3}$ and $\mathbf{4}$ with DNA duplex of sequence d(CGCGAATTCGCG) $)_{2}$ (PDB ID: 1BNA) which affords an energetically favorable 
docked pose (Figure S11 in Supplementary Information). Herein, the comparative resulting docked model displayed both the complexes fit adequately into the curved contour of the targeted DNA in the minor groove through aromatic rings located within narrower G-C rich region as compared to A-T regions leading to number of non-bonding interaction such as van der Waals interaction and hydrophobic contacts with DNA functional groups that define the stability of groove. ${ }^{82}$ Eminently, the interactions of chemical species into the minor groove of B-DNA vary from those securing in the major groove, both in terms of the electrostatic potential and steric effects in view of the narrow shape of the former. In comparison to the major groove, due to small steric interference, small molecules preferentially interact within the minor groove. ${ }^{83}$ The minimum binding energies of the docked metal complexes ( $\mathbf{3}$ and $\mathbf{4})$ were found to be -4.0 and $-3.6 \mathrm{kcal} / \mathrm{mol}$, respectively. The more negative relative binding energy of complex 3 indicates more potent binding between DNA and target molecules. Thus, the experimental results obtained from spectroscopic techniques substantiate the results scored from the molecular docking, hence providing further evidence of groove binding.

\section{Conclusions}

12-membered Schiff base macrocyclic metal complexes were prepared with isatin and 3,4-diaminobenzophenone and characterized by various spectroscopic and physicochemical techniques which confirmed the formation, stoichiometry and bonding nature. Further, the comparative DNA-binding studies revealed the greater complex-DNA interaction for $\mathrm{Cu}$ (II) complex (3) with the exploration of the groove binding mode confirmed by circular dichroism and docking studies. In addition, the DPPH radical scavenging activity results proved that these complexes exhibited scavenging potential. The synthesized complexes possess the significant potential for antibacterial activity against different bacterial and fungal strains. Hence, on account of these observations, it is concluded that the promising binding and biological nature of the $\mathrm{Cu}$ (II) complex could pave the way for designing more effective metal-based drugs.

\section{Supplementary Information (SI)}

Additional information pertaining to characterization of the macrocyclic complexes using FTIR spectrum (Figure S1), NMR spectrum $\left({ }^{1} \mathrm{H}\right.$ and ${ }^{13} \mathrm{C}$ ) (Figure $\mathrm{S} 2$ ), ESI-MS spectra (Figure S3), electronic absorption spectra (Figure S4), EPR spectra of $\mathrm{Cu}$ (II) and $\mathrm{Co}$ (II) (Figure S5), TGA/DTA curves (Figure S6), Plots of CT-DNA binding experiments (Figure
S7), CD spectra of CT-DNA with varying concentration of compounds (Figure S8), antibacterial (a) and antifungal activity (b) of Schiff base macrocyclic complexes (Figure S9), SEM images showing the effect of Schiff base macrocyclic complex of $\mathrm{Cu}$ (II) (3) on bacterial cell (Figure S10) and molecular docked structure (Figure S11), thermal degradation analysis (Table S1), DNA binding studies (Table S2), antimicrobial activity measurements (Table S3) and references are provided in Supplementary Information which is available at www.ias.ac.in/chemsci.

\section{Acknowledgements}

Authors are thankful to the Professor M. Shakir, Chairman, Department of Chemistry, Aligarh Muslim University, Aligarh, India for providing necessary facilities for research. Authors are highly indebted to the Punjab University Chandigarh for providing CHN analysis, NMR and ESI-Mass spectra and IIT Guwahati for EPR studies. Nausheen Bano is thankful to University Grants Commission (UGC) for financial assistance. The facilities given to the department under SAP-DRSII, FIST and PURSE programs are highly acknowledged.

\section{References}

1. Bayri A and Karakaplan M 2007 Theoretical approach to the magnetic properties of $\mathrm{Mn}(\mathrm{II}), \mathrm{Cr}(\mathrm{III})$ and $\mathrm{Cu}(\mathrm{II})$ complexes in the newly reported 12- and 15-membered macrocyclic ligands Pramana-J. Phys. 69301

2. (a) Liu C M, Xiong G, You X Z and Liu Y J 1996 Crystal structure and some properties of a novel potent $\mathrm{Cu}_{2} \mathrm{Zn}_{2} \mathrm{SOD}$ model schiff base copper(II) complex $\left\{[\mathrm{Cu}(\mathrm{bppn})]\left(\mathrm{ClO}_{4}\right)_{2}\right\}_{2} . \mathrm{H}_{2} \mathrm{O}$ Polyhedron 15 4565; (b) West D X, Liberia E, Padhye S B, Chikate R C, Sonawane P B, Kumar A S and Yeranda R S 1993 Thiosemicarbazone complexes of copper(II): structural and biological studies Coord. Chem. Rev. 123 49; (c) Holla B S, Veeredra B, Shivanda M K and Poojar B 2003 Synthesis characterization and anticancer activity studies on some Mannich bases derived from 1, 2, 4-triazoles Eur. J. Med. Chem. 38 759; (d) Priya N P, Arunachalam S, Manimaran A, Muthupriya D and Jayabalakrishnan C 2009 Mononuclear Ru(III) Schiff base complexes: Synthesis, spectral, redox, catalytic and biological activity studies Spectrochim. Acta A $\mathbf{7 2} 670$

3. Singh D P, Malik V, Kumar K, Sharma C and Aneja K R 2010 Macrocyclic metal complexes derived from 2,6diaminopyridine and isatin with their antibacterial and spectroscopic studies Spectrochim. Acta A $\mathbf{7 6} 45$

4. (a) Singh D P, Parveen R Kumar R Surain P and Aneja K R 2014 Spectroscopic and antimicrobial studies of macrocyclic metal complexes derived from 1,8diaminonaphthalene and dimedone $J$. Incl. Phenom. Macro. 78 363; (b) Gerbeleu N V, Arion V B and Burges J 1999 Template Synthesis of Macrocyclic Compounds (Weinheim: Wiley-VCH)

5. (a) Shakir M, Bano N, Rauf A, Kazmi S and Alam M 2017 Synthesis and characterization of pharmacologically active 18 -membered tetraamide macrocyclic complexes of $\mathrm{Mn}(\mathrm{II}), \mathrm{Co}(\mathrm{II}), \mathrm{Ni}(\mathrm{II}), \mathrm{Cu}(\mathrm{II})$, and $\mathrm{Zn}(\mathrm{II})$ : 
In-vitro antimicrobial, anticancer screening, DNA interaction and docking studies Inorg. Nano-Met. Chem. 47 576; (b) Raman N 2009 Synthesis, spectral characterization, in-vitro antimicrobial evaluation and DNA cleavage studies of few macrocyclic complexes J. Indian Chem. Soc. 861143

6. Sakyan I, Logoglu E, Arslan S, Sari N and Sakiyan N 2004 Antimicrobial activities of N-(2-hydroxy-1naphthalidene)-amino acid (glycine, alanine, phenylalanine, histidine, tryptophane) Schiff bases and their manganese(III) complexes Biometals 17115

7. Maimon E, Zilbermann I, Golub G, Ellern A, Shames A I, Cohen H A and Meyerstein D 2001 Comproportionation and redox catalyzed isomerization of $\mathrm{Cu}$ (II) $(1 \mathrm{R}, 4 \mathrm{~S}, 8 \mathrm{R}, 11 \mathrm{~S}-1,4,8,11$-tetramethyl-1,4,8,11tetraazacyclotetradecane $)^{2+}$ in aqueous solutions Inorg. Chim. Acta 32465

8. Kidwai M, Jahan A and Mishra N K 2014 Isatins: a diversity orientated biological profile Med. Chem. 4451

9. Bhrigu B, Pathak D, Siddiqui N, Alam M S and Ahsan W 2010 Search for Biological Active Isatins: A Short Review Int. J. Pharm. Sci. Drug Res. 2229

10. Walsh O M, Meegan M J, Prendergast R M and Nakib T A 1996 Synthesis of 3-acetoxyazetidin-2-ones and 3-hydroxyazetidin-2-ones with antifungal and antibacterial activity Eur. J. Med. Chem. 31989

11. (a) Sharma K, Parveen, Singh D P and Chopra R 2015 Antibacterial and spectroscopic studies of biologically active macrocyclic complexes of divalent metal ions Der Pharma Chem. 7 292; (b) Singh D P, Grover V, Kumar K and Jain K 2011 Synthesis and characterization of divalent metal complexes of the macrocyclic ligand derived from isatin and 1,2-diaminobenzene J. Serb. Chem. Soc. 76385

12. Singh D P, Kumar K and Sharma C 2010 New 14membered octaazamacrocyclic complexes: Synthesis, spectral, antibacterial and antifungal studies Eur. J. Med. Chem. 451230

13. Pisoschi A M, Cheregi M C and Danet A F 2009 Total antioxidant capacity of some commercial fruit juices: electrochemical and spectrophotometrical approaches Molecules 14480

14. (a) Biradar J S, Sasidhar B S and Parveen R 2010 Synthesis, antioxidant and DNA cleavage activities of novel indole derivatives Eur. J. Med. Chem. 45 4074; (b) Valko M, Leibfritz D, Moncol J, Cornin M T, Mazur M and Telser J 2007 Free radicals and antioxidants in normal physiological functions and human disease Int. J. Biochem. Cell Biol. 39 44; (c) Fernandes A S, Gaspar J, Cabral M F, Caneiras C, Guedes R, Rueff J, Castro M, Costa J and Oliveira N G 2007 Macrocyclic copper(II) complexes: Superoxide scavenging activity, structural studies and cytotoxicity evaluation J. Inorg. Biochem. 101849

15. Sasikumar J M, Patharaj J, Adithya E S, Christabel P H and Shamna R 2012 Antioxidant capacity and phenolic content of Elaeagnus kologa schlecht. An underexploited fruit from India Free Radicals Antioxid. 228

16. Agrawal S, Kulkarni G T and Sharma V N 2011 A comparative study on the antioxidant activity of methanolic extracts of Terminalia paniculata and Madhuca longifolia Free Radicals Antioxid. 162
17. Krug M and Hilgeroth A 2008 Recent advances in the development of Multi-Kinase Inhibitors Mini-Rev. Med. Chem. 81312

18. (a) Motzer R J, Hutson T E, Tomczak P, Michaelson M D, Bukowski R M, Rixe O, Oudard S, Negrier S, Szczylik C and Kim S T 2007 Sunitinib versus Interferon Alfa in Metastatic Renal-Cell Carcinoma New Engl. J. Med. 356 115; (b) Xiang Q, Wang F, Su X, Liang Y, Zheng L, Mi Y, Chen W and Fu L 2011 Effect of BIBF 1120 on reversal of ABCB1-mediated multidrug resistance Cell. Oncol. 3433

19. O'Donnell F, Smyth T, Ramachandran V and Smyth W 2010 A study of the antimicrobial activity of selected synthetic and naturally occurring quinolines Int. J. Antimicrob. Ag. 3530

20. Stewart P and Costernon J 2001 Antibiotic resistance of bacteria in biofilms. Lancet $\mathbf{3 5 8} 135$

21. Panwar R, Pemmaraju S C, Sharma A K and Pruthi V 2016 Efficacy of ferulic acid encapsulated chitosan nanoparticles against Candida albicans biofilm Microb. Pathog. 9521

22. Lewis K 2001 Riddle of biofilm resistance Antimicrob. Agents Chemother. 45999

23. Mah T F and O'Toole G A 2001 Mechanisms of biofilm resistance to antimicrobial agents Trends Microbiol. 934

24. Frank J F 2001 Microbial attachment to food and food contact surfaces Adv. Food Nutr. Res. 43319

25. Kojic E M and Darouiche R O 2004 Candida infections of medical devices Clin. Microbiol. Rev. 17255

26. Hawser S P and Douglas L J 1994 Biofilm formation by Candida species on the surface of catheter materials in-vitro Infect. Immun. 62915

27. Aendekerk S, Diggle S P, Song Z, Høiby N, Cornelis P, Williams P and Ca'mara M 2005 The MexGHI-OpmD multidrug efflux pump controls growth, antibiotic susceptibility and virulence in Pseudomonas aeruginosa via 4-quinolone-dependent cell-to-cell communication Microbiology 1511113

28. Hong J, Jiao Y, Yan J, He W, Guo Z, Zhu L and Zhang J 2010 DNA cleavage promoted by trigonal-bipyramidal zinc(II) and copper(II) complexes formed by asymmetric tripodal tetradendate 2-[bis(2aminoethyl)amino]ethanol Inorg. Chim. Acta 363793

29. Huang K B, Chen Z F, Liu Y C, Li Z Q, Wei J H, Wang M, Xie X L and Liang H 2013 Platinum(II) complexes containing aminophosphonate esters: Synthesis, characterization, cytotoxicity and action mechanism Eur. J. Med. Chem. 64554

30. Huang, R, Wallqvist A and Covell D G 2005 Anticancer metal compounds in NCI's tumor-screening database: putative mode of action Biochem. Pharmacol. 691009

31. Ranford J D, Sadler P J and Tocher D A 1993 Cytotoxicity and antiviral activity of transition-metal salicylato complexes and crystal structure of Bis(diisopropylsalicylato) (1,10phenanthroline)copper(II) Dalton Trans. 223393

32. Li Y, Yang Z Y and Wang M F 2009 Synthesis, characterization, DNA binding properties and antioxidant activity of Ln(III) complexes with hesperetin-4-one-(benzoyl) hydrazone Eur. J. Med. Chem. 444585

33. Pravin N and Raman N 2014 Investigation of in-vitro anticancer and DNA strap interactions in live cells using 
carboplatin type $\mathrm{Cu}(\mathrm{II})$ and $\mathrm{Zn}(\mathrm{II})$ metalloinsertors Eur. J. Med. Chem. 85675

34. Shakir M, Hanif S, Sherwani M A, Owais M, Azam M and Resayes S I A 2016 Pharmacophore hybrid approach of new modulated bis-diimine $\mathrm{Cu}^{\mathrm{II}} / \mathrm{Zn}^{\mathrm{II}}$ complexes based on 5-chloro Isatin Schiff base derivatives: Synthesis, spectral studies and comparative biological assessment J. Photochem. Photobiol. B 15739

35. Ramos-Sanchez M C, Rey F J, Rodriguez M L, MartinGil F J and Martin-Gil 1988 DTG and dta studies on typical sugars J. Thermochim. Acta 13455

36. Alaghaz A N M A and Ammar R A 2010 New dimeric cyclodiphosph(V) azane complexes of $\mathrm{Cr}(\mathrm{III}), \mathrm{Co}(\mathrm{II})$, $\mathrm{Ni}(\mathrm{II}), \mathrm{Cu}(\mathrm{II})$, and $\mathrm{Zn}(\mathrm{II})$ : Preparation, characterization and biological activity studies Eur. J. Med. Chem. 45 1314

37. Seth B K, Ray A, Saha A, Saha P and Basu S 2014 Potency of photoinduced electron transfer and antioxidant efficacy of pyrrole and pyridine based $\mathrm{Cu}$ (II)-Schiff complexes while binding with CT-DNA J. Photochem. Photobiol. B 13272

38. Kavitha P, Saritha M and Reddy K L 2013 Synthesis, structural characterization, fluorescence, antimicrobial, antioxidant and DNA cleavage studies of $\mathrm{Cu}$ (II) complexes of formyl chromone Schiff bases Spectrochim. Acta A 102159

39. El-Sonbati A Z, Diab M A, El-Bindarya A A, Ghoneim M M, Mohesien M T and Abd El-Kader M K 2016 Polymeric complexes-LXI. Supramolecular structure, thermal properties, SS-DNA binding activity and antimicrobial activities of polymeric complexes of rhodanine hydrazone compounds J. Mol. Liq. 215711

40. Sheikhshoaie I, Ebrahimipour S Y, Lotfi N, Mague J T and Khaleghi M 2016 Synthesis, spectral characterization, X-ray crystal structure and antimicrobial activities of two cis dioxido-vanadium(V) complexes incorporating unsymmetrical dimalonitrile-based (NNO) Schiff base ligands Inorg. Chim. Acta 442151

41. Mares D 1989 Electron microscopy of Microsporum cookei after 'in-vitro' treatment with protoanemonin: A combined SEM and TEM study Mycopathologia 10837

42. (a) Siddiqi Z A, Khan M, Khalid M and Kumar S 2007 Spectral and electrochemical characterization of bimetallic complexes of a novel 32-membered unsymmetrical $\left[\mathrm{N}_{12}\right]$ macrocycle Transition Met. Chem. 32 927; (b) Athappan P R and Rajagopal G 1996 Synthesis, spectroscopic and redox behaviour of copper(II), nickel(II) and cobalt(II) complexes of some macrocyclic multidentates Polyhedron 15527

43. Singh A K, Singh R and Saxena P 2004 Macrocyclic metal complexes: synthesis and characterization of 14and 16- membered tetraaza macrocyclic complexes of transition metals Transition Met. Chem. 29867

44. Casas J S, Castellano E E, Tasende M S G, Sanchez A and Sordo J 2000 Reaction of dimethylthallium(III) acetate and isatin-3-thiosemicarbazone. Crystal and molecular structure of dimethyl (dimethylsulfoxide) (isatin-3thiosemicarbazonato) thallium(III) Inorg. Chim. Acta 304283

45. Asadi M, Sepehrpour $\mathrm{H}$ and Mohammadi $\mathrm{K}$ 2011 Tetradentate Schiff base ligands of 3,4diaminobenzophenone: Synthesis, characterization and thermodynamics of complex formation with $\mathrm{Ni}(\mathrm{II})$, $\mathrm{Cu}$ (II) and Zn(II) metal ions J. Serb. Chem. Soc. 7663

46. Aqra F M A M 1999 New macrocyclic complexes containing amide, imine and secondary amine functions Transition Met. Chem. 24337

47. Labisbal E, Sousa A, Castineiras A, Vazquez J A G, Romero J and West D X 2000 Spectral and structural studies of metal complexes of isatin 3hexamethyleneiminylthiosemicarbazone prepared electrochemically Polyhedron 191255

48. Rahaman F and Mruthyunjayaswamy B H M 2014 Synthesis, spectral characterization and biological activity studies of transition metal complexes of Schiff base ligand containing indole moiety Complex Met. 188

49. Niasari M S and Amiri A 2006 Synthesis and characterization of Bis(macrocyclic) Nickel(II) complexes containing aromatic nitrogen-nitrogen linkers produced by template condensation Transition Met. Chem. 31157

50. Raman N and Thangaraja C 2005 Synthesis and structural characterization of a fully conjugated macrocyclic tetraaza (14)-membered Schiff base and its bivalent metal complexes Transition Met. Chem. 30317

51. Menteşe E 2013 Efficient microwave assisted synthesis of some new benzimidazoles containing the mebendazole nucleus J. Chem. Res. 37168

52. Haribabu J, Subhashree G R, Saranya S K, Gomathi R, Karvembu and Gayathri D 2016 Isatin based thiosemicarbazone derivatives as potential bioactive agents: antioxidant and molecular docking studies J. Mol. Struct. 1110185

53. Yousif E, Majeed A, Sammarrae K A, Salih N, Salimon J and Abdullah B Metal complexes of Schiff base: Preparation, characterization and antibacterial activity Arab. J. Chem. https://doi.org/10.1016/j.arabjc.2013.06.006.

54. Sahin D, Koçoglu S, Sener O, Senol C, Dal H, Hokelek $\mathrm{T}$ and Hayval Z 2015 New NO donor ligands and complexes containing furfuryl or crown ether moiety: Syntheses, crystal structures and tautomerism in orthohydroxy substituted compounds as studied by UV-vis spectrophotometry J. Mol. Struct. 1102302

55. (a) Omar M M and Mohamed G G 2005 Potentiometric, spectroscopic and thermal studies on the metal chelates of 1-(2-thiazolylazo)-2-naphthalenol Spectrochim. Acta A 61 929; (b) Lever A B P 1968 Inorganic Electronic Spectroscopy 1st edn. (Amsterdam: Elsevier); (c) Chandra S and Pundir M 2007 Spectral studies of cobalt(II) complexes of 12-membered macrocyclic ligands having thiosemicarbazone moieties Spectrochim. Acta A 68883

56. Figgis B 2000 Ligand field theory and its applications 1 st edn. (New York: John-Wiley)

57. Siddiqi Z A, Siddique A, Shahid M, Sharma P K, Khalid M and Yogi A 2013 Synthesis and characterization of homo-dinuclear complexes $\left[\mathrm{M}_{2}(\mathrm{dea})_{2}\left(\mathrm{H}_{2} \mathrm{O}\right)_{4}\right],\left[\mathrm{M}_{2}(\mathrm{dea})_{2}(\mathrm{Bipy})_{2}\right]$ and $\left[\mathrm{Fe}_{2}(\mathrm{dea})_{2}\left(\mathrm{H}_{2} \mathrm{O}\right)_{2}(\mathrm{Cl})_{2}\right] \quad(\mathrm{M}=\mathrm{Co}, \mathrm{Ni}$ or $\mathrm{Cu}$; $\mathrm{H}_{2}$ dea $=$ diethanolamine): ${ }^{57} \mathrm{Fe}$ Mössbauer and electrochemical investigations J. Mol. Struct. 1036209

58. (a) Kivelson D and Neiman R 1962 ESR studies on the bonding in copper complexes J. Chem. Phys. 35 149; (b) Garribba E and Micera G 2006 The determination of the geometry of $\mathrm{Cu}$ (II) complexes: An EPR spectroscopy experiment J. Chem. Educ. 83 1229; (c) Raman 
N, Thangaraja C and Johnsonraja S 2005 Synthesis, spectral characterization, redox and antimicrobial activity of Schiff base transition metal(II) complexes derived from 4-aminoantipyrine and 3-salicylideneacetylacetone Cent. Eur. J. Chem. 3537

59. Kneubuhl F K 1960 Line shapes of electron paramagnetic resonance signals produced by powders, glasses, and viscous liquids J. Chem. Phys. 331074

60. Proctor I M, Hathaway B J and Nicholls P 1968 The electronic properties and stereochemistry of the copper(II) ion. Part I. Bis(ethylenediamine)copper(II) complexes J. Chem. Soc. (A) 1678; (b) Ray A, Rosair G M, Kadam R and Mitra S 2009 Three new mono-di-trinuclear cobalt complexes of selectively and non-selectively condensed Schiff bases with $\mathrm{N}_{2} \mathrm{O}$ and $\mathrm{N}_{2} \mathrm{O}_{2}$ donor sets: Syntheses, structural variations, EPR and DNA binding studies Polyhedron 28 796; (c) Chandra S and Gupta L K 2005 Spectroscopic studies on Co(II), $\mathrm{Ni}(\mathrm{II})$ and $\mathrm{Cu}(\mathrm{II})$ complexes with a new macrocyclic ligand: 2,9-dipropyl-3,10-dimethyl-1,4,8,11-tetraaza5,7:12,14-dibenzocyclotetradeca-1,3,8,10-tetraene Spectrochim. Acta A $\mathbf{6 1} 1181$

61. Sharma S, Athar F, Maurya M R, Naqvi F and Azam A 2005 Novel bidentate complexes of $\mathrm{Cu}(\mathrm{II})$ derived from 5-nitrofuran-2-carboxaldehyde thiosemicarbazones with antiamoebic activity against E. histolytica Eur. J. Med. Chem. 40557

62. Pandya J H, Jadeja R N and Ganatra K J 2014 Spectral characterization and biological evaluation of Schiff bases and their mixed ligand metal complexes derived from 4,6-diacetylresorcinol J. Saudi Chem. Soc. 18190

63. Khan M I, Khan A, Hussain I, Khan M A, Gul S, Iqbal M, Rahman I U and Khuda F 2013 Spectral, XRD, SEM and biological properties of new mononuclear Schiff base transition metal complexes Inorg. Chem. Commun. 35 104

64. Ramachandran E, Raja D S, Bhuvanesh N S P and Natarajan K 2012 Mixed ligand palladium(II) complexes of 6-methoxy-2-oxo-1,2-dihydroquinoline3-carbaldehyde 4N-substituted thiosemicarbazones with triphenylphosphine co-ligand: Synthesis, crystal structure and biological properties Dalton Trans. 4113308

65. Li Y, Wu Y, Zhao J and Yang P 2007 DNA-binding and cleavage studies of novel binuclear copper(II) complex with 1,10 -dimethyl-2,20 -biimidazole ligand J. Inorg. Biochem. 101283

66. Xi P X, Xu Z H, Liu X H, Chen F J and Zeng Z Z 2008 Synthesis, characterization, antioxidant activity, and DNA-binding studies of 1-cyclohexyl-3-tosylurea and its $\mathrm{Nd}(\mathrm{III}), \mathrm{Eu}(\mathrm{III})$ complexes Chem. Pharm. Bull. 56541

67. Chen H, Ahsan S S, Berrios M B S, Abruna H D and Webb W W 2010 Mechanisms of quenching of Alexa fluorophores by natural amino acids J. Am. Chem. Soc. 1327244

68. Sarwar T, Rehman S U, Husain M A, Ishqi H M and Tabish M 2015 Interaction of coumarin with calf thymus DNA: Deciphering the mode of binding by in vitro studies Int. J Biol. Macromol. 739

69. (a) Song G, Yan Q and He Y 2005 Studies on Interaction of Norfloxacin, $\mathrm{Cu}^{2+}$, and DNA by Spectral Methods $J$. Fluoresc. 15 673; (b) Asatkar A K, Tripathi M, Panda
S, Pande R and Zade S S $2017 \mathrm{Cu}(\mathrm{I})$ complexes of bis(methyl)(thia/selena) salen ligands: Synthesis, characterization, redox behavior and DNA binding studies Spectrochim. Acta A 17118

70. (a) LePecq J B and Paoletti C 1967 A fluorescent complex between ethidium bromide and nucleic acids: Physical-Chemical characterization J. Mol. Biol. 27 87; (b) Kumar B V, Naik H S B, Girija D, Sharath N, Pradeepa S M, Hoskeri H J and Prabhakara M C 2012 Synthesis, DNA-binding, DNA-photonuclease profiling and antimicrobial activity of novel tetra-aza macrocyclic $\mathrm{Ni}(\mathrm{II}), \mathrm{Co}(\mathrm{II})$ and $\mathrm{Cu}$ (II) complexes constrained by thiadiazole Spectrochim. Acta A 94192

71. Kumar P, Baidya B, Chaturvedi S K, Khan R H, Manna D and Mondal B 2011 DNA binding and nuclease activity of copper(II) complexes of tridentate ligands Inorg. Chim. Acta 376264

72. (a) Rajendran A and Nair B U 2006 Unprecedented dual binding behaviour of acridine group of dye: A combined experimental and theoretical investigation for the development of anticancer chemotherapeutic agents Biochim. Biophys. Acta 1760 1794; (b) Shahabadi N, Kashanian S and Darabi F 2010 DNA binding and DNA cleavage studies of a water soluble cobalt(II) complex containing dinitrogen Schiff base ligand: the effect of metal on the mode of binding Eur. J. Med. Chem. 45 4239

73. Maheswari P U and Palaniandavar M 2004 DNA binding and cleavage properties of certain tetrammine ruthenium(II) complexes of modified 1,10-phenanthrolineseffect of hydrogen bonding on DNA-binding affinity $J$. Inorg. Biochem. 98219

74. (a) Bindu P, Kurup M R P and Satyakeerty T R 1998 EPR, cyclic voltammetric and biological activities of copper(II) complexes of salicylaldehyde N(4)-substituted thiosemicarbazone and heterocyclic bases Polyhedron 18 321; (b) Singh R P, Murthy K C N and Jayaprakasha G K 2002 Studies on the antioxidant activity of pomegranate (Punica granatum) peel and seed extracts using in vitro models J. Agric. Food Chem. 5081

75. (a) John R P, Sreeknth A, Rajakannan V, Ajith T A and Kurup M R P 2004 New copper(II) complexes of 2-hydroxyacetophenone $N(4)$-substituted thiosemicarbazones and polypyridyl co-ligands: structural, electrochemical and antimicrobial studies Polyhedron 232549 ; (b) Ravichandran J, Gurumoorthy P, Karthick C and Kalilur Rahiman A 2014 Mononuclear zinc(II) complexes of 2-((2-(piperazin-1-yl)ethylimino) methyl)-4substituted phenols: Synthesis, structural characterization, DNA binding and cheminuclease activities J. Mol. Struct. 1062147

76. Kesavan M P, Kumar G G V, Raja J D, Anitha K, Karthikeyan S and Rajesh J 2017 DNA interaction, antimicrobial, antioxidant and anticancer studies on $\mathrm{Cu}$ (II) complexes of Luotonin A J. Photochem. Photobiol. $B 16720$

77. Corbin B D, Seeley E H, Raab A, Feldmann J, Miller M R, Torres V J K L, Anderson, Dattilo, B. M, Dunman, P M, Gerads R, Caprioli, R M, Nacken W, Chazin W J and Skaar E P 2008 Metal chelation and inhibition of bacterial growth in tissue abscesses Science 319 962 
78. Nitha L P, Aswathy R, Mathews N E, Kumari B S and Mohanan K 2014 Synthesis, spectroscopic characterisation, DNA cleavage, superoxidase dismutase activity and antibacterial properties of some transition metal complexes of a novel bidentate Schiff base derived from isatin and 2-aminopyrimidine Spectrochim. Acta A 118 154

79. Chohan Z H, Pervez H, Rauf A, Khan K M and Supuran C T 2004 Isatin-derived Antibacterial and Antifungal Compounds and their Transition Metal Complexes J. Enzyme Inhib. Med. Chem. 19417

80. Mohanan K, Devi S N and Murukan B 2006 Complexes of Copper(II) with 2-(N-Salicylideneamino)-3carboxyethyl-4,5,6,7-tetrahydrobenzo[b] thiophene Containing Different Counter Anions Syn. React. Inorg. Met. Org. Nano-Met. Chem. 36441
81. Sherwani M A, Tufail S, Khan A A and Owais M Gold Nanoparticle-Photosensitizer Conjugate Based Photodynamic Inactivation of Biofilm Producing Cells: Potential for Treatment of C. albicans Infection in BALB/c Mice PLoS ONE. https://doi.org/10.1371/journal.pone. 0131684 July 6, 2015

82. Filosa R, Peduto A, Micco S D, Caprariis P D, Festa M, Petrella A, Capranico G and Bifulco G 2009 Molecular modelling studies, synthesis and biological activity of a series of novel bisnaphthalimides and their development as new DNA Topoisomerase II inhibitors Bioorgan. Med. Chem. 1713

83. Corradini R, Sforza S, Tedeshi T and Marchelli R 2007 Chirality as a tool in nucleic acid recognition: Principles and relevance in biotechnology and in medicinal chemistry Chirality 19269 